\title{
Establishment of A Small Scale Non-Woven Tissue Processing Industry
}

\author{
Lawal, A.S and Andrew, A.M \\ Department Of Textile Science And Technology Ahmadu Bello University, Main Campus, Zaria, Nigeria
}

\begin{abstract}
A study was made to establish a site for the tissue manufacturing industry. The industry is proposed to be located in the Northern part of Nigeria. It will be situated on a 615,204 square meters area, which is to be acquired prior to erection of building and other infrastructure. The major raw materials include obsolete/waste paper, carton and chipboards. The types, of machines to be used are pulper machines, chester machine, tissue recycling machine, culling machine and slicing machine. The initial capital outlay for the plant is $\$ 75$ million for a start. The product will generate a total revenue over a period of three years of $\$ 97$ million with a net fixed asset of $\$ 54 . S$ million. Thus, the project is feasible even at an annual discount of $10 \%$.
\end{abstract}

\section{Introduction}

The non-woven industries manufacturer a diversity of product such as tissues, diapers, and tea bags which are different in end uses (Nkeonye, 2009), sell in many markets and employ production organizations varying in size and complexity from a few workers to several thousands in a series of factories (Cliffs, 1980). These non-woven industries rest on a common technology of bonding or interlocking of fibres or both which can be accomplished by mechanical, chemical, hermal or solvent means and combination of both (Krcma, 1971; Phyllis, 1998). Presently, there are few numbers of nonwoven manufacturing plants, however, they don't start from raw materials to finishing, except one which supplies the Northern part of the country with secondary products (Pizzito, 1977). The current production figures are high which is an indication of the lucrative nature of the industry. However, there is an indication that all these industries have not met local demands. It is reasonable to say that all these non-woven manufacturing plants cannot supply more than $20 \%$ of the quantity demanded locally leaving about $80 \%$ of the market requiring to be filled. This is in addition to the possibility of exportation to the nearby African countries especially the community of West African States (Enrick, 1975; Cliffs, 1980).

This suggests a very generous market outlay for non-woven products. Furthermore, the increase in population, automobile, fashion (body and loot wears) machines, agricultural products, etc, will cause an increase in the local demand of non-woven products (Mark, 1985).

\section{Materials}

\section{Experimental}

The major raw materials include obsolete/ waste papers, carious or chipboards. The types of machines to be used are pulper machine, Chester machine, tissue paper recycling machines, culling machine and slicing machine.

\section{Production Technique}

The waste papers, cartons or chipboards arc fed into the pulper machine in the unit; they are washed clean and soaked to soften in a reservoir. The product is then fed into the Chester machine where bleaching agents are added to bleach the material if required (John, 1993). The product in turn is fed into the tissue-recycling machine, where production takes place with application of adhesive in the finishing section. The finishing section comprises of finishing I, and finishing II, and lastly in to the packaging section where the products are packed after being sliced by the slicing machine or culling machine (Cliffs, 1980; Mark, 1985). 


\section{Results and Discussion}

\section{Analysis of Results}

Table I: Description of the Activities and Their Duration

\begin{tabular}{|l|l|l|}
\hline Activity & Description & $\begin{array}{c}\text { Duration } \\
\text { (Weeks) }\end{array}$ \\
\hline A & Feasibility report & 4 \\
B & Negotiation with technical partners/financers consultant registration & 4 \\
C & Procurement of land & 2 \\
D & Screening and recruitment of senior staff & 1 \\
E & Procurement of machines equipment and other accessories & 3 \\
F & Building design, plants and blue prints & 5 \\
G & Surveying, filling, reclaiming of land, lining up sites with roads, electricity and water supply & \\
& & 3 \\
H & Erection of building (starting with factory) structures, plumbing and other installations & 5 \\
I & Procurement o raw materials and other accessories & 40 \\
J & Installation of machines and equipment & 1 \\
K & Recruitment and training of other staff & 9 \\
L & Start up and test running & 4 \\
M & Final adjustment of machines & 3 \\
N & Commissioning of plant & 2 \\
O & & $\mathbf{8 7}$ weeks \\
\hline Total &
\end{tabular}

Table II: Capital Cost

\begin{tabular}{|l|l|}
\hline Fixed Asset & Cost Estimate $(\mathrm{N})$ \\
\hline Land & $3,000,000$ \\
Building equipment & $10,000,000$ \\
Furnitures and fittings & $1,000,000$ \\
Machines & $12,000,000$ \\
Electricity and water & $10,000,000$ \\
Vehicles & $13,000,000$ \\
Computer and accessories & $6,000,000$ \\
Medical equipment & $4,000,000$ \\
Miscellaneous expenses & $5,000,000$ \\
\hline Total & $55,000,000$ \\
\hline
\end{tabular}

Table III: balance Sheet for the Three Years

\begin{tabular}{|c|c|c|c|}
\hline Capacity Utilization & $1^{\text {st }}$ Year $(\mathbb{N})$ & $2^{\text {nd }}$ Year $(\mathrm{N})$ & $3^{\text {rd }}$ Year $(\mathrm{N})$ \\
\hline Fixed asset & $55,000,000$ & $55,000,000$ & $55,000,000$ \\
\hline Less depression & 500,000 & 500,000 & 500,000 \\
\hline Net fixed asset & $54,500,000$ & $54,500,000$ & $54,500,000$ \\
\hline
\end{tabular}

Table IV: Analysis of raw Materials Cost Estimate

\begin{tabular}{|c|c|c|c|c|}
\hline Raw Materials & $1^{\text {st }}$ Year $(\mathbb{N})$ & $2^{\text {nd }}$ Year $(\mathrm{N})$ & $3 \mathrm{dr}$ Year $(\mathrm{N})$ & Total (N) \\
\hline Waste papers & $10,150,000$ & $16,100,000$ & $20,025,000$ & $46,275,000$ \\
\hline Cartons & $2,202,600$ & $4,108,200$ & $10,100,000$ & $16,410,800$ \\
\hline Chipboards & $3,536,200$ & $6,310,200$ & $8,023,000$ & $17,869,400$ \\
\hline Total & $15,888,800$ & $26,518,400$ & $38,148,000$ & $80,555,200$ \\
\hline
\end{tabular}

Table V: Analysis of Profit and Loss Estimate

\begin{tabular}{|l|l|l|l|}
\hline Year & $\begin{array}{c}\text { Expenditure (Cost of Raw } \\
\text { Materials + Labour ) (\#) }\end{array}$ & $\begin{array}{c}\text { Income (Cost of Finished } \\
\text { Products) (\#) }\end{array}$ & Gain (\#) \\
\hline $1^{\text {st }}$ year at 60\% production & $20,000,000$ & $35,000,000$ & $15,000,000$ \\
\hline $2^{\text {nd }}$ year at 80\% production & $32,000,000$ & $50,000,000$ & $18,000,000$ \\
\hline $3^{\text {rd }}$ year at 100\% production & $15,000,000$ & $65,000,000$ & $20,000,000$ \\
\hline Total & $97,000,000$ & $150,000,000$ & $53,000,000$ \\
\hline
\end{tabular}

\section{Discussion}

The industry is proposed to be located in the Northern part of Nigeria. It will be situated on a 615,204 square meters area, which is to be acquired prior to erection of building and other infrastructure. Table I showed the various activities that are required to be implemented as well as their durations. The project is estimated to take a period of eighty-seven weeks for completion. The production of tissue will be three shifts of eight hours, each scheduled as follows:
i. Morning shift:
$6.00 \mathrm{am}-2.00 \mathrm{pm}$.
ii. Afternoon shift:
$2.00 \mathrm{pm}-10.00 \mathrm{pm}$.
iii. Nightshirt:
$10.00 \mathrm{pm}-6.00 \mathrm{am}$.

Suppose that the forecast is rated as $100 \mathrm{~kg}$ of product per hour, for an eight hours shift, the machine will 
produce:

$100 \times 24=2400 \mathrm{~kg}$ per day

$2,400 \times 6=144,000 \mathrm{~kg}$ per week

$144,000 \times 52=748,000 \mathrm{~kg}$ per year

It is proposed that in the first year the production will be at $60 \%$ capacity and about full capacity of $100 \%$

will commence in the third year. The firm being a new one will require atleast three years for stabilization.

Hence the forecast of the cost analysis is for five years but only the first three years will be considered, as the remaining two years will be as the third year at $100 \%$ production, Thus, the forecast will be cost analyzed by $60 \%$ production at the first year, $80 \%$ for the second year and $100 \%$ for the third year. There are several categories of human labour to be employed in this firm and they include:

i. General hand.

ii. Semi skilled labourers.

iii. Skilled labourers.

iv. Technicians.

v. Supervisors.

vi, Administrative staff.

vii. Managers.

The total estimate of the labour force is put at $\$ 571,000$ per month. Hence in a year, the estimate will be $\$ 571,000 \times 12=\$ 6,852,000$. Therefore,

For the first year at $60 \%$ capacity,

Labour cost $=60 / 100 \times 6,852,000=\$ 4,111,200$

For the second year at $80 \%$ capacity,

Labour cost $=80 / 100 \times 6,852,000=\$ 5,481,600$

For the third year at $100 \%$ capacity,

Labour cost $=100 / 100 \times 6,852,000=\$ 6,852,000$.

Total labour cost (salary) for the three years:

$=4,111,200+\$ 5,481,600+\$ 6,852,000=\$ 16,444,800$.

Therefore, totaling the cost above, the firm is to be set up will a minimum of the following: Capital cost

Cost of raw material for the $1^{\text {st }}$ year

Labour cost for the $1^{\text {st }}$ year

$=\$ 55,000,000$

Total

$$
\begin{aligned}
& =\$ 15,888,800 \\
& =\mathrm{N} 4,111,200 \\
& =\$ 75,000,00
\end{aligned}
$$

For the three consecutive years under review out of the five years forecast as shown in Table V.

Total expenditure

Total income

$$
=\$ 97,000,000
$$

Total gain

$=\$ 150,000,000$

$=$ Total income - Total expenditure

$=\$ 150,000,000-\$ 97,000,000$

$=\$ 53,000,000$

Thus,

Percentage gain for the three years under review

$$
\begin{aligned}
& =\text { Total gain } \quad \times 100 \\
& \text { Total expenditure } \\
& =53,000,000 \\
97,000,000_{-} & \\
& =54.6 \%
\end{aligned}
$$

The fourth and fifth years are assumed to make even a higher gain or same as the third year, since the third year is a settlement year, any year from the third year upwards is expected to have a higher or equal gain.

\section{Conclusion}

The analysis showed that the firm when set up would be a profitable firm, which has a $54.6 \%$ gain in full capacity production. With a net fixed asset of 45.6 million, the company has a better chance of attracting investors and funding from other agencies. The firm can also expand as it stabilizes for the production of other non-woven products such as sanitary pads and tea bags, hence more profit can be made. Expected increment both in local and international market is also viable. The work provides a guide as well as the cost estimate of setting up a tissue manufacturing plant. However, this is an estimate, the real cost could be slightly higher or lower. 


\section{References}

[1]. Cliffs, E.N.J. (1980) Encyclopedia of Textiles. Third Edition, Doric Publishing Company U.S.A., Vol. 1, P. $383-393$

[2]. Krcma, R. (1971). Manual of Non-woven. The Textile Trade Press Manchester, U.K. P. 13-82.

[3]. Pizzito, J.J. (1977). Fabric Science. Fourth Edition. Fair Child Publications Inc. New York, Vol. 1, P. $193-197$.

[4]. Mark, B. (1985). Encyclopedia of Polymer Science and Engineering. Second Edition, P.J. Publications New York, Vol. 10, P. 204227.

[5]. Enrick, L. (1975). Management Control Manual for the Textile Industry. Published by Textile Institute Manchester, U.K., P. 5-18.

[6]. John, L. (1993). Performance of Textiles. John Willey and Sons Publication, New York, P. 35

[7]. Phyllis, G. (1998). Understanding Textile. Published by Macmillan Company Inc., New York, U.S.A., P. $3357-360$.

[8]. Nkeonye, P.O. (2009). Introductory Textiles. Asekome and Co. Publishers, Samaru, Zaria, Nigeria. P. 8-20. 